\title{
15. The Belief in Sorcery in Solomon Islands
}

\author{
Philip Kanairara and Derek Futaiasi
}

\section{Introduction}

Solomon Islands was primarily governed by customary law or custom before the protectorate era, which commenced in 1893. People still embrace their customs and cultures today even with the introduction of many changes affecting how people think and how things are done. Preferring customary ways to settle disputes, practising customary dances, tattooing, and weaving of mats and baskets are some examples of how people still embrace their customs.

People also have strong beliefs in custom rituals and magic. These rituals and magic are believed to have good and bad causes. Belief in the magic of sorcery is an example of a belief that is still strong and alive in Solomon Islands society.

Sorcery today is an offence under both state and customary laws in Solomon Islands.

State law (the Penal Code [Cap 26] Section 190) refers to sorcery as:

i) the performance of any magical ritual where there is a general belief among a class of persons that may result in harm to any person; or

ii) the possession of articles (without lawful excuse) commonly associated by any class of persons with harmful magic.

Under custom, sorcery in Solomon Islands can refer to an act or action that causes serious sickness or illness that could result in misfortune, insanity or death if no customary means of cure is given to the victim.

Sorcery can be for a good ${ }^{1}$ or bad cause. As to the latter, two common examples in Solomon Islands of the belief in sorcery are arua in Malaita Province and vele in Guadalcanal Province.

\footnotetext{
1 Antisocial behaviours are low for fear of sorcery; or sorcery provides the community the reason for death, sickness, insanity and misfortune.
} 
Arua is a term given to a sorcery practice in which a male or female takes food scraps or a piece of clothing of another person and feeds it to a snake or frog or rat. This is mainly practised in some parts of Malaita.

Vele means "to pinch", from the tingling or pinched feeling in the arms that warns protected persons of the proximity of the vele magician' (Wright 1940:203).

According to Wright (1940:204), 'The usual method employed by the vele man is to hide by the side of a road and, as the victim approaches, to make a sharp noise, thus attracting attention. The man turns and sees the vasa ${ }^{2}$ suspended from a finger. He collapses, usually in an unconscious condition.' This method is practised in Guadalcanal.

In 1932 in Ontong Java, Malaita Province, Ian Hogbin reported that:

When a sorcerer decided to kill a man, there were several ways in which it might be done. One was to get hold of something closely connected with him, - his hair, nail-parings, or saliva, the last being the favourite. The sorcerer watched where his victim spat, and subsequently took the wet earth and worked his spells over it. Very soon the man would sicken and, if not treated, would die. Another method was to make spells over some such object as a stone, a human bone, or a few grains of sand. During the night the sorcerer took this and either threw it into the house of the victim or buried it near the door. This was equally fatal. The third way was to make an effigy out of pandanus leaf and stick skewers through it. As each one was put in, the man is said to have felt a sharp stab of pain. (Hogbin 1932:442)

He went on to say '[t]he spells, like all others at Ongtong Java, were direct appeals to the spirits of the ancestors' (Hogbin 1932:442-43).

Accusations of sorcery arise today because of several factors that include:

- jealousy due to social and economic advancement

- customary land disputes between different clans and tribes

- criminal activities within villages

- friendship breakdown.

2 The instrument in which the magical power of vele resides, a small bag made of fibre containing articles such as sacred earth, pieces of shrub or creeper, a man's tooth, and a short piece of native shell money. 
Sickness, death, insanity or misfortune are widely believed to be possible results of bad sorcery. ${ }^{3}$

This chapter has five parts. Part 1 focuses on some common perceptions ${ }^{4}$ about sorcery in Solomon Islands. Part 2 briefly highlights some negative social consequences of the belief in sorcery. Part 3 deals with customary governance of sorcery. Part 4 deals with state governance of sorcery, and the final part suggests some ways forward and options for law reform.

\section{Part 1: People's views on the belief in sorcery}

The Solomon Islands Law Reform Commission (SILRC) conducted consultations in Solomon Islands in 2009 and 2010 on the review of the Penal Code. Sorcery was an issue highlighted by many people as being of serious concern in society and needing to be addressed by the government. The problem of sorcery was raised by many respondents, even though it was not a subject they were directly asked to comment upon. Below are some examples of views on sorcery expressed to the SILRC from people from Choiseul, Temotu, Isabel, Western, Malaita and Makira provinces:

- Sorcery causes harm to human life. Sorcerers should be categorised as murderers. Sorcery can result in mental illness, bad luck and death. Capital punishment (death) should be the punishment for sorcerers. Sorcery is caused by power, self-defence and jealousy. ${ }^{5}$

- Sorcery is a main concern and is happening on a massive scale today. It is very common that when a person died, the death is often linked to an alleged sorcerer. In the past in custom, death was the penalty for practising sorcery. Sorcery should be seriously considered and its penalty should be equivalent to that of a murderer. ${ }^{6}$

\footnotetext{
3 See also Bennett (1987:18), who said: 'Solomon Islanders attributed major troubles to the actions of sorcerers. In the Melanesian's view nothing happened by chance; people attempted to channel spiritual forces to their own ends. Consequently whatever happened - be it illness, a famine, death of a pig, the falling of a branch onto a child, the achievement of leadership, or victory in a battle - all occurred because someone had access to power from the spirits. One major way of gaining access was through sorcery, with the sorcerer using magical ritual to invoke a deity, an ancestral spirit, or less commonly, a demon spirit. Sorcery was universal and, in its negative aspects, greatly feared. A form of social control, it usually restrained the more ruthless and exploitive members of the community and ensured conformity to socially accepted moral values.'

4 No detailed consultation was conducted by the Solomon Islands Law Reform Commission on sorcery. The views in this paper are the ones people expressed during the general consultation on the review of the Penal Code.

5 Frank Waetara, Toroa village, Makira Province, verbal submission over mobile phone to the SILRC, 2010.

6 Tom Firilanga, Malu'u, North Malaita, Malaita Province, verbal submission to SILRC, 2010.
} 
- Sorcery disturbs the community. Those who practise sorcery should be punished accordingly. The sorcery offence should include threat to commit sorcery. ${ }^{7}$

- Sorcery in Solomon Islands is an act of murder. ${ }^{8}$

- Law should recognise customary law that deals with sorcery. The chiefs should deal with sorcery disputes. Use of witchcraft like black magic for house breaking is common. ${ }^{9}$

- Evidence of sorcery could be a report from the chief. Most deaths are believed to be caused by sorcery. Law needs to recognise death by sorcery. At the moment church leaders and chiefs conducted reconciliation and counselling to parties. Penalty for sorcery should be one of deterrence purpose. ${ }^{10}$

- Black magic or sorcery is widespread. There are more deaths caused by sorcery than other means. Law should recognise sorcerers as equal to murderers. People report sorcery incidents to the church. One alleged sorcerer was beaten to death because of sorcery. The church has gone on missions to collect evidence used in black magic. ${ }^{11}$

The central message from the above perceptions is that sorcery is a serious concern in society. The variety of views suggested the state, church and community leaders should be responsible for dealing with the sorcery offence.

The SILRC is actively working on the review of the sorcery offence as part of the review of the Penal Code and Criminal Procedure Code Reference, and is currently conducting consultations on this review. The end product of the review will be a report containing recommendations for law reform which will be sent to the government through the minister responsible for justice.

\section{Part 2: Effects of the belief in sorcery}

Today in Solomon Islands, belief in sorcery is leading to criminal activities. Some of these negative social effects are criminal offences such as assault, arson and murder.

In 2012, according to the Isabel provincial police commander, unlawful activities related to sorcery had increased in the highlands of Isabel Province (Kakai 2012). In 2010, relatives of a dead man burnt down two homes in separate villages in Central Kwara'ae, Malaita Province, because they suspected their relative had

\footnotetext{
SILRC Consultation meeting with Gizo Police, Western Province, 2009.

SILRC Lata Public Forum Consultation, Temotu Province, 2010.

SILRC Taro consultation, Choiseul Province, 2009.

10 SILRC Bula consultation, Provincial Council of Women, Isabel Province, 2009.

11 SILRC Bula consultation, Diocese of Isabel, Isabel Province, 2009.
} 
died due to a type of sorcery commonly known in the area as kelema (Kakai 2010). In this case, the police did not act because nobody reported the matter to them. In 2009 in East Kwaio, Malaita Province, a pagan priest who was suspected of practising sorcery was stabbed to death (Radio Australia 2009). These were some instances that suspected sorcerers were harmed and banished from living in communities. ${ }^{12}$

Furthermore, so-called customary healers or customary doctors sometimes take advantage of the strong beliefs in sorcery to commit sexual offences like rape and indecent assault in the name of curing or healing female victims from sorcery-belief sickness. An example is the case of $R v$. Tebounapa. ${ }^{13}$ In this case the customary doctor who was the accused was convicted for raping the complainant. He had sexual intercourse with the complainant during a massage session that was aimed at removing a devil from the complainant. First, the accused told the complainant that if she thought about her children, she must let him have sexual intercourse with her. He told the complainant that without sexual intercourse with her, the sickness would not be cured. The accused told the complainant that the purpose of sexual intercourse was to remove the dirty water from her body caused by poison (sorcery). If this was not done, she would die the following month. Also in this case, the same accused was convicted of indecent assault because the accused during the course of curing another complainant played with the clitoris of the complainant. The accused told the complainant that he had been given power and anointed by the chiefs to do such work. He told the complainant not to be afraid of him despite the occurrence of such sexual acts.

Rape was also committed in the case of Regina $v$. Sisiolo. ${ }^{14}$ In this case, the accused claimed to be a customary doctor. He also claimed to be someone who could predict the future. Because of his alleged background, he was allowed to cure a young girl who was believed to be a victim of sorcery. In the course of trying to cure the girl Sisiolo had sexual intercourse with her. Sisiolo claimed that a remedy to cure the alleged sorcery caused to the female complainant was sexual intercourse with her.

12 Authors' knowledge of the effects of sorcery.

$13 R$ v. Tebounapa [1999] SBHC 1; www.paclii.org.vu.

14 Regina v. Sisiolo [2010] SBHC 35; www.paclii.org.vu. 


\section{Part 3: Customary governance of sorcery}

In the past, sorcerers were killed if they were deemed responsible for the death of other persons (Ofasia 2003). ${ }^{15}$ Such payback killing could be executed by the relatives of the deceased.

In other instances, sorcerers were banished from the village or community. In one part of Malaita, the sorcerer would be represented by a coconut placed in the $b a e^{16}$ as an affirmation that they would not return. Sometimes they were asked to pay compensation before they left.

At present, chiefs or traditional leaders sometimes deal with sorcery because it is a customary wrong. An example was in 2010 in Malaita Province where chiefs were asked to deal with a sorcery case. A house of chiefs inquired into the matter and ordered the alleged sorcerer to pay 10 red shell valuables as compensation to the relatives of the deceased. The alleged sorcerer paid the compensation. ${ }^{17}$

Proving sorcery according to custom is different to the requirements of the state courts. Chiefs and other traditional elders have the knowledge and ability to prove sorcery according to customary acceptable standards. This is because although the practices or rituals of sorcery are done in secret, a person who practises sorcery is noticeable in the community. A sorcerer is suspected in the community by his or her strange behaviour. This includes strange things that are observed to happen at the sorcerer's home. For example, snakes or frogs are regularly found in the home of the alleged sorcerer or lying in cooking pots or on plates.

In North Malaita (Toabaita and Lau) custom there are two common methods of proving sorcery. These methods both involve tracing. However, people's acceptance of these methods is an issue.

The first method of tracing is to trace any contact that the victim had with the sorcerer. For example, the sorcerer might have given some food to the victim or might have taken a piece of the victim's clothes. Any illness caused to the victim after his or her contact with the sorcerer is always suspected to be due to sorcery. Further, if the sorcerer's home was frequented by snakes or frogs, or if these

15 See also SILRC interview with Chief John Konai, Matakwalao House of Chiefs, North Malaita, Malaita Province, 2013; SILRC interview with Rinaldo Talo, president, Malaita Local Court, Malaita Province, 2013.

16 Place where people are buried.

17 SILRC interview with Chief John Konai, Matakwalao House of Chiefs, North Malaita, Malaita Province, 2013. The authors were unable to get information from the interviewee as to how the chiefs came to the conclusion that the alleged sorcerer was responsible for the death. 
were found in cooking pots and plates, this proves the suspicions according to customary standards of belief and proof. This method is still commonly known today although not used to pronounce somebody as a sorcerer. ${ }^{18}$

The other method of finding the sorcerer is the use of spiritual ritual (called sule akalo). This method involves tribal leaders who are specialised in spiritual callings to call the dead person's spirit to lead them to the sorcerer's home. At the grave the expert person will call the deceased's spirit. The deceased's spirit in the form of a firefly (bubulu) will lead the expert and his group to the sorcerer's house. The firefly will rest on the sorcerer's house. This method is no longer used to prove someone a sorcerer in the community. ${ }^{19}$

Denial of being a sorcerer is a common response of alleged sorcerers. However, in some cases alleged sorcerers admit that they have magical objects for protection and not to cause harm. In some instances, the alleged sorcerers can point out the source of their magical objects to well-known customary healers in the community.

\section{Part 4: State governance of sorcery}

\section{State legal system}

Sorcery is an offence in Solomon Islands. The Penal Code [Cap 26] in Section 190 provides:

Any person who

(a) performs any magic ritual in respect of which there is a general belief among any class of persons that harm may be caused to any person; or

(b) has in his possession, without lawful excuse, any article commonly associated by any class of persons with harmful magic,

is guilty of a misdemeanour, and shall be liable to imprisonment for two months or to a fine of forty dollars.

There are two problems with this provision. First, this sorcery offence provision does not fully reflect sorcery as it is known and understood in Solomon Islands society. This is because sorcery as it is known to Solomon Islanders is an act that causes serious sickness or illness that could result in misfortune, insanity or death if no customary means of cure is given to the victim. A sorcerer is

18 The authors of this chapter were unable to get information on why the method was not used.

19 The authors of this chapter were unable to get information on why the method was not used. 
known to the victim when the victim experiences misfortune or becomes sick. While sick, the victim may repeatedly dream about the sorcerer. Or the sorcerer becomes known to relatives of the victim after the victim dies. The relatives can use the two tracing methods described above to identify the sorcerer. ${ }^{20}$ These are the customary beliefs and perceptions as to how a sorcerer is identified. This is different to the sorcery offence as envisaged in Section 190(a) that provides for criminalisation of performance of any magical ritual where there is a general belief among a class of persons that may result in harm to any person; and under Section 190(b) that provides for criminalisation of possession of articles (without lawful excuse) commonly associated by any class of persons with harmful magic. This is because performing rituals and possessing articles (objects) are only partial factors for identifying a sorcerer in customary ways.

Second, the sorcery provision in the Penal Code has not been used to prosecute any alleged sorcerer(s) in the past. ${ }^{21}$ The reason for this non-usage is because of the perception that the sorcery offence as in Section 190 of the Penal Code is difficult to prove. ${ }^{22}$ This perception is due to the fact that sorcery conduct or dealings are done in secret. For instance, the performance of magic ritual and possession of harmful magic objects or articles are hidden from those who do not practise sorcery. The only people who may have a chance of witnessing the conduct or articles are close family members. Except in rare cases, these family members will not reveal the sorcerer because of the stigma that is associated with sorcery. They will not wish to be seen and considered as an evil family in the community. There was an instance that a child revealed that her mother was practising sorcery. ${ }^{23}$ This instance is discussed below under the Local Court Act.

The perception that the sorcery offence is difficult to prove needs to be tested in court. This is because although sorcerers perform their magical rituals in secret or hide their magical articles, there are times they can be caught. For example, a sorcerer who practises arua often dances in the graveyard after the victim is buried. This type of practice is considered to be a ritual that is associated with harm. A vele sorcerer often has in possession a special vele bag. This object is commonly known as possessed by those with harmful magic. There might be some successful cases if cases of the sorcery offence were tried in courts, especially the local court and magistrate court. ${ }^{24}$

\footnotetext{
20 The problem with these methods is that they are not currently used.

21 SILRC email correspondence with Mr Douglas Hou of the Public Solicitor's Office, Mr Ricky Iomea of the Director of Public Prosecutions and Mr Galvin Ora of the Police Prosecutions Office. Also SILRC conversation by telephone with Mr Leonard Maina, chief magistrate of Solomon Islands.

22 SILRC email correspondence with Mr Galvin Ora of the Police Prosecutions Office.

23 SILRC interview with Rinaldo Talo, president, Malaita Local Court, Malaita Province, 2013.

24 The local court is the relevant court to deal with sorcery offences. The magistrate court is mentioned because it is the court that currently deals with matters that are under the local court jurisdiction as the local court is not active at the moment.
} 
Another reason for the non-usage of this provision may be because of the low penalty attached to the offence. ${ }^{25}$ This does not reflect the nature of the offence in custom as sorcery is a very serious wrong in custom. ${ }^{26}$ A suggestion for a higher penalty to deter people from practising sorcery was proposed during consultation. ${ }^{27}$

\section{Regina v. Havimana case}

This is a case ${ }^{28}$ where sorcery was discussed by the court in the context of a defence to a charge of murder. The defendant attempted to rely on the argument that he killed the victim because the victim had killed his father by sorcery. The defence alleged that the sorcerer revealed himself through two other victims (Eldon Kari and Veronica Lestro - not killed) when two Church of Melanesia Brothers conducted clearance and healing in the area. The Brothers used holy water, holy oil and prayer in their clearance and healing sessions. It was alleged by the defence witnesses that the victim in this case (alleged sorcerer) was speaking through Eldon Kari and Veronica Lestro saying that he was responsible for killing the accused's father, the late Reverend Ambrose Havimana. The alleged sorcerer was alleged to speak through Eldon and Veronica when they were made asleep by the Brothers. The High Court of Solomon Islands did not accept this method (voice identification through the victims in which the alleged sorcerer was identified) because of inconsistent evidence given by the defence witnesses.

It is not clear how the defence wished to advance its case in relation to its argument that the alleged sorcerer was responsible for the death of the accused's father. This is because it is not clear as to what would be the legal consequences of the court accepting Allen (the deceased in the case) as the sorcerer of the accused's father. That is, what benefit would the court render to the accused on the basis that the accused committed payback murder for the sorcerer killing his father? Would the court agree to extend provocation to cover that circumstance? The court in this case did not make any statement on this issue.

\section{Local Court Act [Cap 19]}

The Local Court Act allows for the local courts to deal with minor civil and criminal matters where parties are all islanders residing within the jurisdiction of the local courts as set out in their warrants that established them (Section 6). The Act allows the local courts to apply islander custom in the area of the

\footnotetext{
25 The maximum penalty for the sorcery offence in the Penal Code is imprisonment of two months or a fine of SBD40.

26 SILRC interview with Rinaldo Talo, president, Malaita Local Court, Malaita Province, 2013.

27 SILRC interview with Rinaldo Talo, president, Malaita Local Court, Malaita Province, 2013.

28 Regina v. Havimana [2011] SBHC 48; www.paclii.org.vu.
} 
jurisdiction of the courts (Section 16). The courts can hear both the law and customary wrongs or breaches. They can impose punishment authorised by law or custom of the islanders that is not contrary to natural justice and humanity, and the punishment must always be proportionate to the nature and circumstances of the offence (Section 18).

The local courts can deal with sorcery offences both under state law (Penal Code) and under customary law. Under state law a local court can deal with a sorcery offence because it is a minor offence and if the parties are from the area of jurisdiction of the local court. However, there is no evidence (according to the authors' research) to show that a local court has dealt with a sorcery offence under state law. On its customary jurisdiction, a local court can deal with sorcery as a customary wrong. This is because sorcery is a customary wrong and custom determines the punishment for alleged sorcerers. Custom recognised death, banishment, or giving of land to the victim or victim's family as forms of punishment for sorcerers (Nanau 2011; Ofasia 2003; authors' personal knowledge). According to the authors' research there were two instances where the Malaita local court, under its customary law jurisdiction, dealt with the accusation of practising sorcery. The first case involved a wife who was accused of causing the death of her husband by sorcery. The community suspected the wife of having arua because she danced and talked in the graveyard in the night during moonlight and a customary ritual was performed and found that the wife was responsible for the death. During the local court hearing, the daughter of the wife testified that her mother fed a 'cat' in the bush. The daughter led the court officers to the place in the bush and they found a half snake (snake without a tail) in the area. The local court found the wife guilty of sorcery according to custom and ordered her to pay five red shell valuables to the husband's side. ${ }^{29}$

The second case was Are v. Makau. ${ }^{30}$ In this case, the plaintiffs (husband and wife, wife accused of being a sorcerer) brought the case to the local court to make appropriate orders against the defendants for accusing the wife as a sorcerer. The facts of the case were Rebecca Koobira, wife of Are, was sick and got healing or deliverance from a Church of Melanesia Brother (tasiu). The first defendant, Selly Makau, went with Rebecca and witnessed the healing process. Rebecca was unconscious during the healing process. The Brother told her that she would see some signs within the next three days. During the three days, Rebecca passed blood and then she passed a dead snake on the third day. This snake was believed to be an arua given to her. She could feed the arua and use it to poison people. Selly told this story about Rebecca to others, including Are. Are (the husband) was not happy about the story and went to the local court for

29 The authors were unable to get further information about this case.

30 Malaita Local Court, Civil Case No. 1 of 2012 (judgment delivered 22 April 2013). 
appropriate orders. The court ruled that Selly only informed others about the true happenings or story about Rebecca. The local court did not give any orders for damage or compensation to the plaintiffs. Instead the court ruled that:

i) Rebecca not to initiate any rare actions to raise suspiciousness;

ii) Parties are not to spread false news of arua; and

iii) Parties are to reconcile.

Apart from the above two cases, the Malaita local court dealt with many cases in relation to rare or extraordinary behaviour of alleged sorcerers during times of death. ${ }^{31}$ Claimants came to court claiming compensation from alleged sorcerers, accusing them of behaving extraordinarily during times of death. The extraordinary behaviours include laughing out loud persistently, putting flowers on heads and eating a lot during the mourning period. The court awarded compensation for such claims because these extraordinary behaviours amount to customary wrongs. ${ }^{32}$

\section{Provincial government level}

\section{Moli Ward Chiefs Council Ordinance 2010}

At the provincial level, the Guadalcanal Provincial Assembly passed the Moli Ward Chiefs Council Ordinance 2010 (Moli Ward Ordinance) establishing the Moli Ward Chiefs Council and providing it with powers to deal with matters within the Moli Ward in accordance with customary law and practices of the tribes of Moli Ward and for related matters. Among others, the Moli Ward Ordinance stipulated that sorcery is an offence.

Section 77 of the ordinance states:

A person who practices sorcery in Moli Ward breaches this section and is liable to a fine not exceeding 1,000 penalty units and one pig, one chausangavulu, ${ }^{33}$ and one chupu. ${ }^{34}$

In this section, 'sorcery' means any rituals for which there is a general belief among any class of persons that harm may be caused to any person or in possession, without lawful excuse, any article commonly association in any class of persons with harmful magic, and include

\footnotetext{
31 These cases were mainly seeking customary compensation for the rare actions of the respondents but not accusations of practising sorcery.

32 SILRC interview with Rinaldo Talo, president, Malaita Local Court, Malaita Province, 2013.

33 Chausangavulu refers to 10 string shell money of one fathom each string in length.

34 Chupu refers to the piles of cooked food, uncooked garden produce, live pigs and shell money that are exchanged in ceremony which may be made for a range of purposes (Monson 2012:229-30).
} 
heathen practices or black magic commonly known in Moli Ward as piro, vele, or kibokibo for which there is a general belief among any class of persons may cause harm.

All evidences in sorcery matters shall be by way of eye witness, circumstantial or admissions.

Hearsay evidence is inadmissible and cannot be accepted as evidence against a defendant.

The offence except the penalty closely reflects the sorcery offence in the Penal Code. Proving an offence under the Moli Ward Ordinance is just as problematic as under the Penal Code. Admission of guilt is difficult as alleged sorcerers do not generally confess in Solomon Islands. The closest admission of guilt that an alleged sorcerer will make is to say that he or she has something for protection and not for killing or harming someone. Circumstantial evidence could therefore be the only possible way to prove someone is guilty of sorcery. For example, in the case of someone with arua, facts such as the alleged sorcerer was recently in contact with the victim by giving food to the victim, and evidence of frogs and snakes in the sorcerer's home, are circumstantial evidence that can be argued in a state-supported court. However, whether a court will accept such evidence is uncertain - only the courts will give a position on this.

\section{Part 5: Options for law reform and ways forward}

The first option as a way forward for law reform is to use the local court customary jurisdiction to deal with sorcery. The Local Court Act [Cap 19] establishes the legal framework to recognise, apply and use customary law in the rural areas of Solomon Islands. It allows the local courts under its customary jurisdiction to determine or settle customary disputes or wrongs. The local courts also have the power to direct an accused or a respondent to pay compensation to a victim - more towards restorative justice. The problem at the moment is that the local court is not fully utilised to perform its customary jurisdiction. The local courts were active in the past but not now (Evans et al. 2010). Currently, the local courts are operated more in the provincial centres as opposed to the local rural areas as the Local Court Act envisaged. Also, currently, the local courts focus more on customary land disputes other than customary wrongs and breaches, and minor criminal and civil cases. ${ }^{35}$ This makes it impossible for serious customary wrongs like sorcery, adultery and fornication (adultery and fornication are not criminal

35 The authors' personal knowledge with the justice system of Solomon Islands. 
offences under the state law) to be settled at the local courts. The result is that people resort to self-help approaches of asking compensation and assaulting the accused in sorcery, adultery or fornication cases. This sometimes results in escalation of violence in the communities. This could be avoided if local courts functioned to their full capacity.

Under its customary jurisdiction, the Local Court Act should clarify that local courts are to have unlimited jurisdiction to order or give punishment or sentence on customary wrongs or breaches appropriate to the seriousness of the wrong in custom. This unlimited jurisdiction, however, must be subject to natural justice and humanity as provided for in Section 18 of the Local Court Act. This suggestion is made on the basis that the Act is not clear as to sentences the local court can award under its customary jurisdiction. A broad interpretation of the Act would mean that the local court has unlimited jurisdiction and can award any sentence according to custom so long as the sentence is not inconsistent with natural justice and humanity. ${ }^{36}$ In contrast, a narrow interpretation of the Act would mean that the local court can only award a sentence for criminal matters of a fine of no ore than SBD200 or no more than 6 months imprisonment. And for civil matters the local court can only award up to SBD1,000 for damages or compensation. ${ }^{37}$

In the past when local courts were active, they upheld customary laws, which on appeal to the high court were also upheld. This was reflected in the To'ofilu $v$. Oimae case. ${ }^{38}$ In that case, the high court ruled that the customary practice of determining payment of bride price would be best dealt with by the local court of the area of which both parties originated. Similarly, sorcery as a customary wrong should be best dealt with by local courts.

The second option is to devolve jurisdiction over sorcery to the customary legal system. The chiefs or traditional leaders' customary forum is good because they have the knowledge about sorcery practices. ${ }^{39}$ Given their know-how about sorcery they can deal effectively with it. For instance, the move by the Guadalcanal provincial government through the ordinance in empowering the Moli Ward Chiefs Council to deal with sorcery is a step in the right direction. Such an approach should be carefully considered at the national level to see if it can be adopted as a solution for addressing sorcery more widely.

Finally, the third option is to consider the involvement of churches to deal with sorcery. The Church of Melanesia is involved in dealing with sorcery on request by communities by way of blessing shrines and neutralising the habitats of

36 This interpretation is based on custom as the determining factor subject to natural justice and humanity.

37 See warrants that established the different local courts.

38 To'ofilu $v$. Oimae [1997] SBHC 33; paclii.org.vu.

39 See Futaiasi (2011) for a discussion of the advantages and challenges facing customary forums. 
dangerous spirits. Brothers of the Church of Melanesia on request visit villages to do what is termed 'clearance' or 'deliverance'. This process involves going to villages and collecting items associated with sorcery or talking to people who are suspected of practising sorcery. They usually urge those who practise sorcery to stop doing sorcery and come forward to the Brothers for healing purposes. An issue with this option is whether such church programs will accept taking a step further to settle disputes between parties as a result of sorcery.

An additional aspect that must be done if local courts, councils of chiefs or houses of chiefs, and church officials are to be involved in dealing with sorcery is for the state to provide training for them in areas of natural justice, human rights principles and other basic law principles. The training will empower them to conduct and discharge fair hearings and settlements for parties who seek remedies from them. Further, the councils of chiefs or the houses of chiefs and the church officials who are to deal with sorcery must register their groups with the local courts. This will ensure proper coordination and oversight over the groups dealing with sorcery.

\section{References}

Bennett, J.A. 1987. Wealth of the Solomons: A History of a Pacific Archipelago, 1800-1978. Honolulu: University of Hawai'i Press.

Evans, D., M. Goddard and D. Paterson 2010. The Hybrid Courts of Melanesia: A Comparative Analysis of the Village Courts of Papua New Guinea, Island Courts of Vanuatu and Local Courts of Solomon Islands. Justice and Development Working Paper Series No. 13. Washington DC: World Bank. documents.worldbank.org/curated/en/2010/01/14276330/hybrid-courtsmelanesia-comparative-analysis-village-courts-papua-new-guinea-islandcourts-vanuatu-local-courts-solomon-islands, viewed 22/4/2014.

Futaiasi, D.L.G. 2011. Advantages and Challenges Facing Custom Dispute Determination and Settlement: An Assessment. In A Study of Customary Methods Dealing with Customary Land Disputes in Malaita, Solomon Islands. LLM Research Paper. University of the South Pacific, 91-108.

Hog bin, H.I. 1932. Sorcery at Ontong Java. American Anthropologist 34(3):441-48.

Kakai, J. 2010. No Police Action on Burnt Homes. Solomon Star 2 December.

Kakai, J. 2012. Sorcery on the Rise in Isabel: PPC. Solomon Star 9 June. 
Monson, R. 2012. Hu Nao Save Tok? Women, Men and Land: Negotiating Property and Authority in Solomon Islands. PhD thesis, The Australian National University.

Nanau, G.L. 2011. The Wantok System as a Socio-Economic and Political Network in Melanesia. OMNES: The Journal of Multicultural Society 2(1):31-55. www.omnesjournal.org/upload/public/pdffile/10/1.pdf, viewed 3/5/2013.

Ofasia, J. 2003. Traditional Toabaitan Methods of Forgiveness and Reconciliation. Melanesian Journal of Theology 19(2):6-39. www.cltc.ac.pg/LinkClick. aspx?fileticket=Dv2joj3F_mY\%3D\&tabid=80, viewed 20/3/2013.

Radio Australia 2009. Hunt for Three Murder Suspects in Solomon Islands Linked to Sorcery. Radio Australia 16 March. www.radioaustralia.net.au/ international/radio/onairhighlights/hunt-for-three-murder-suspects-insolomon-islands-linked-to-sorcery, viewed 10/2/2013.

Wright, L.W.S. 1940. The 'Vele' Magic of the South Solomons. The Journal of the Royal Anthropological Institute of Great Britain and Ireland 70(2):203-9. 
This text is taken from Talking it Through: Responses to Sorcery and Witchcraft Beliefs and Practices in Melanesia, edited by Miranda Forsyth and Richard Eves, published 2015 by ANU Press, The Australian National University, Canberra, Australia. 